\title{
Rivalries Cause Friction
}

Berlin March 8th /89

My dear Mr. Kasson:

.... I am grieved to know such bad reports of the Emperor are rife in America. Still I thank you for telling me, as it gives oppor'y (opportunity) to let you know the truth. A malicious set of Jews are here, who thinking it unlikely the Emperor wd befriend them, have put their heads together to injure him in every possible way they can both on this and our side the water and preaching up want of filial feeling as their best capital they work straight through lies. No truth in what they say for that is not their stronghold-it helps to "push the bad forward" and that's enough for them.

I think I am in position to know and I can truly say I have not heard the first word as uttered by the Emperor ${ }^{1}$ against his royal mother, he was a dutiful son very fond of his father and with him all that was possible. After his death Emperor managed everything in a most praiseworthy manner and is popular here. He keeps the royal family in mourning until the middle of June and after the anniversaries of death and burial of his father at Potsdam. I have read somewhere that by a law of Prussia if heir to the throne had an incurable malady, it (the throne) must pass to next heir. I don't know if its true, but if it is I've never heard of the Emperor even hinting such a thing. As far as I know he has always treated his mother Empress Frederic with greatest respect.

You doubtless have heard of Dr. Mackenzie when has was first called to Berlin to attend the Crownprince. Grand Duchess of Baden then staying with her father told Mary the English Dr made light of her brother's trouble, was using iodine, had cured hundreds of throats of a similar kind and believed he wd cure the Prince. This gave much encouragement. A warmer atmosphere was advised and they went to San Remo. A Gen'l who was much with them dined with us one day, said consultation of six German Drs had decided the case was cancer, but Dr Mac had gained the perfect confidence of the Princess by assuring her it was no cancer and her husband wd be well in a short time. Queen Victoria seemed to cling to the same idea and as a general thing it was so supposed at London. In the illustra'd papers the Prince was made to appear quite himself again. The last print I saw was "Emperor Frederic taking his daily drive in pony chaise" in extensive grounds of palace at Potsdam. He was erect in open chaise and looking quite natural in military garb and giving military salute to the crowd surrounding. At that very time he was in bed and close to the end.

\footnotetext{
${ }^{1}$ Wilhelm II.
} 
$\mathrm{O}$, how much has taken place since I last wrote you-a letter cannot hold it all. I'll come to the time that Emperor Wilhelm II opened parliament, he first directed service in the chapel of the castle, Dr Koegel ${ }^{2}$ preached from the text given by the Emperor "By the Grace of God I am what I am." Mary said the discourse was very solemn and impressive and the Emperor seemed to feel it much. She only staid for religious service, Alfred remained. Emperor, when simply Prince Wm. admired Alfred's military taste and was sure to come when A. lectured to officers. Later Alfred joined him in devotion to his grandfather, thus their friendship strengthened and they are now firm friends. I may say as much for Empress and Mary. They both with her two sisters, Princess of Schleswig Holstein called here on New Year's day and have been here since. I think it wise in Emperor to visit different sovereigns. By so doing he has at least secured the long craved peace, for the present.

My son passed Holidays with us, cn his return voyage came Jan 27th the Emperor's birthday, passengers were mostly German and he wrote their enthusiasm was tremendous. They cheered loudly, emptied many a glass to his honor and ceased not for a long time wishing new Emperor every good possible. He is certainly popular, whatever lies Jews may tell to the contrary. I hope dear Mr. Kasson you will improve every oppor'y to let yr friends know the base origin of the bad reports.

On eve'g previous to birthday Alfred gave a dinner in honor of Emperor of 63 covers-officers of general staff-in great library of this building, first time a meal was ever served there. Next day Alfred dined with Emperor, Mary had herself excused on acct of Sunday. The Prussian Order of Red Eagle has three classes; on this birthday the Emperor gave to Alf'd the highest order, he also made him a life member of Prussian House of Lords. In early Feb. he went there for the first time to take the oath, Mary with him, and it was full of interest for her. This is form of oath, "I, Alfred Count Waldersee swear it, by God's help, through our Lord Jesus Christ to everlasting salvation." Mary said Alfred stood alone and it was very solemn. You may already know of the oath, but it will not harm to tell it in this connection.

I have a lot of good to tell you of our neighbor Moltke .... Last Friday the 8th was 70th anniversary of Moltke's care (?) of Army. He did not wish any notice taken of it, but that was impossible. Emperor, Empress and their three eldest boys came to greet him. Alfred also was there any many others. The better to please, Mary and I held off till next day, a soldier carried our tribute, beautiful arrangement of flowers as clover leaf. We entered the spacious apartment and congratulated the great

2Rudolf Koegel, court preacher. 
Moltke. He cordially welcomed us, showed us many gifts he had rec'd, among them a fine bronze bust of Emperor. In fact his rooms are full of interest. He took us into his own room where he writes so much. I told him for sake of Germany I wished he might live 70 years longer. He bears his age remarkably, no one wd suppose he was over 80 , step still firm . . . .

A friend recently told me she saw at Legation Minister Pendleton. Another told me last night, when speaking of you, that Bismarck was wishing to see you. I think this will raise yr circulation .... Few days ago I was surprised by the coming of Wurtemberg Minister to give from his King to my Mary the "Olga Order," the same he had just given to my daughter "Baroness v. Waechter," in souvenir of the good both were trying to do . . . .

Speaking of Bismarck, a lot of papers declaring entire enmity between Chancellor and Ct. Waldersee may have reached you. Alfred thought such a lie shd be stopt, he wrote note to B. asking him to set a time for him to call. He replied "come at once, I'm always glad to see you." They talked the matter over, parted in most friendly way and had that put in paper.

After our return in autumn Bismarck invited Alfred to pay him a visit at his estate Friedrichsruh. He sent principal aide de camp to station for Alfred and with the Princess warmly welcomed him. Next morn'g he showed Alfred over his grounds, shooting Park etc. etc. He bro't his pipe to Alfred's room, seated himself in an easy-chair and they had a long talk. When time came for leaving Bismarck came himself to station with Alfred and A. was well pleased by his visit-sent you I think a paper telling of great Fete at Russian embassy. 40 were invited to dinner, host and hostess Count and Countess Shouvaloff gave up their places at table to Emperor and Empress so they shd sit opposite. ${ }^{3}$ Herbert Bismarck led in Mary and placed her next the Emperor and the ambassador sat at his right. If I can see you I will tell of little pleasantry between Emperor and Mary ....

Alfred and my Mary join in kindest remembrances and I am now and ever faithfully $\mathrm{yr}$ friend

\section{A. D. LEE}

A less partial observer than her mother also pays tribute to this American-born woman who came to stand in high places, and the Letters of Empress Frederick, published in 1929, allude occasionally to the Countess von Waldersee. The Count, however, was persona non grata. Sir Frederick Ponsonby, editor of the Letters, observes that in 1889 "there was steadily growing in the German

${ }^{3}$ In accordance with the custom that royalty are considered hosts, not guests. 
court .... influence that was destined to have the most deplorable effect upon the Emperor William II. For some years there had been in his immediate entourage a Prussian officer of Chauvinist views-Count von Waldersee, who, in the various campaigns since 1866, had proved his undoubted military ability. In 1881 he became von Moltke's chief of staff, and when Moltke retired Waldersee stepped into his shoes as chief of the general staff. There were now signs of a growing rivalry between Waldersee and the Bismarcks. To her mother Queen Victoria the Empress wrote in July, 1889: "You may have heard about the rivalry between the Bismarcks and Count Waldersee ... It is he who has set William so against me for years!.... Neither the late Emperor William nor Fritz could bear him and distrusted him very much - he is not nearly as clever as Moltke, and a very shifty and changeable individual. She (Countess von Waldersee) is a very good woman but violently Low Church, a partisan of Stöecker's ${ }^{4}$ and a very great friend of Dona's (the Empress, wife of Wilhelm II). The Stöecker party are hated in Germany ...."

County Waldersee, in his reminiscences, refers to newspaper reports at home and abroad to the effect that the Countess had unlimited influence upon the Empress and also upon the Emperor, and there are many allusions to the friendship between them, for instance the Waldersees' visit to Kiel for a royal christening. This intimacy is not difficult to account for, since the Countess' first husband, the Prince of Schleswig Holstein, was a great-uncle of the Empress.

\section{EMPEROR FREDERICK'S IMPENDING DEATH}

The following letters containing less specific comment are from the Countess von Arnim, a minor authoress, wife of Hermann, Count von Arnim, a government official and member of the Reichstag. Perhaps the most interesting part is the feminine remark on that epochal book "The Natural Law in the Spiritual World."

${ }^{4}$ Adolf Stoecker, one of the court preachers, advocate of Christian socialism, member of the Prussian Diet, leader in the anti-semitis movement. 
Copyright of Annals of Iowa is the property of State of Iowa, by \& through the State Historical Society of Iowa and its content may not be copied or emailed to multiple sites or posted to a listserv without the copyright holder's express written permission. However, users may print, download, or email articles for individual use. 